\title{
Phytopathology
}

\section{The Elusive Search for Reniform Nematode Resistance in Cotton}

\author{
Churamani Khanal, ${ }^{\dagger}$ Edward C. McGawley, Charles Overstreet, and Salliana R. Stetina
}

First, second, and third authors: Louisiana State University AgCenter, Department of Plant Pathology and Crop Physiology, Baton Rouge 70803; and fourth author: United States Department of Agriculture-Agricultural Research Service, Crop Genetics Research Unit, P.O. Box 345, Stoneville, MS 38776.

Accepted for publication 6 November 2017.

\begin{abstract}
The reniform nematode (Rotylenchulus reniformis Linford and Oliveira) has emerged as the most important plant-parasitic nematode of cotton in the United States cotton belt. Success in the development of reniform nematode-resistant upland cotton cultivars (Gossypium hirsutum L.) has not been realized despite over three decades of breeding efforts. Research approaches ranging from conventional breeding to triple species hybrids to marker-assisted selection have been employed to introgress reniform nematode resistance from other species of cotton into upland cultivars. Reniform nematode-resistant breeding lines derived from G. longicalyx were developed in 2007 . However, these breeding lines displayed stunting symptoms and a hypersensitive response to reniform nematode infection. Subsequent breeding efforts focused on G. barbadense, G. aridum, $G$. armoreanum, and other species that have a high level of resistance to reniform nematode. Marker-assisted selection has greatly improved screening of reniform nematode-resistant lines. The use of advanced molecular techniques such as CRISPER-Cas9 systems and alternative ways such as delivery of suitable "cry" proteins and specific double-stranded RNA to nematodes will assist in developing resistant cultivars of cotton. In spite of the efforts of cotton breeders and nematologists, successes are limited only to the development of reniform nematode-resistant breeding lines. In this article, we provide an overview of the approaches employed to develop reniform nematode-resistant upland cotton cultivars in the past, progress to date, major obstacles, and some promising future research activity.
\end{abstract}

\section{COTTON}

Cotton (Gossypium spp.) is believed to have originated 5 to 10 million years ago, followed by its separation into three major lineages: American origin, Asian African Origin, and Australian origin (Wendel and Grover 2015). American cotton is known as a New World species while Asian African and Australian are known as Old World species. Originally, cotton was a diploid species with genomes A, B, C, D, E, F, G, and K. Commercially planted upland cotton (Gossypium hirsutum L.) is a tetraploid species, with its "A" genome from the Old World species and the "D" genome from New World species. Nobody knows how these two genomes from New World species and Old World species came together, combined, and gave rise to a tetraploid plant.

The genus Gossypium has more than 50 species, of which two diploid species, G. arboreum L., and G. herbaceum L., and two tetraploid species, G. hirsutum L., and G. barbadense L., are produced commercially (Wallace et al. 2009). Of the cultivated species, G. hirsutum, also known as upland cotton, is the most widely planted.

${ }^{\dagger}$ Corresponding author: C. Khanal; E-mail: ckhana1@1su.edu

(c) 2018 The American Phytopathological Society
Cotton is grown in tropical and subtropical regions of the world, mainly as a textile fiber crop. Worldwide production is estimated to be 125 million bales (Dabbert and Gore 2014; Dighe et al. 2009). Other than as a source of textile fiber, cotton is grown as a source of protein for the animal feed industry (Koenning et al. 2004), a source of lubricants, and a source of high-quality oil equivalent to or better than soybean for human consumption (Mauney and Stewart 1986; Thorp et al. 2014). Cotton has also been regarded as a potential source of biofuel production (Thorp et al. 2014). Other products that are prepared from cotton are cottonseed protein bioplastics, fish nets, coffee filters, bandages, $\mathrm{x}$-ray film, astronaut space suits, and U.S. paper currency (http://www.robinsonlibrary.com/agriculture/ plant/field/cotton.htm).

Cotton production in the United States is intensive and highly mechanized (Koenning et al. 2004, Starr et al. 2007). The United States ranks third in cotton production (Meyer and MacDonald 2016) and shares approximately $10 \%$ of global cotton ending stocks (Meyer 2017). Most of the United States cotton is upland cotton grown as an annual crop (Anonymous 2010). Commercial production of upland cotton is primarily in the southern United States, with concentrations in the Texas High Plains, the southeast, and the Mississippi Delta (Anonymous 2010). Currently Texas, Georgia, and Mississippi are the top cotton producers in the United States (Anonymous 2017). Total upland cotton production in the United States is approximately 16 million bales (Anonymous 2017). 


\section{CONSTRAINTS OF COTTON PRODUCTION}

Cotton production in the United States has significantly increased since World War II. This increase in productivity was mainly brought about by the advent of improved cotton cultivars, relatively low-cost fertilizers, and mechanization in cotton production (Starr et al. 2007). Boll weevils, lepidopteran insects, and weeds were the major constraints in cotton production for many years. Implementation of the Boll Weevil Eradication Program, coordinated by the United States Department of Agriculture, and the advent of transgenic cotton cultivars were very effective in managing major weeds and insects of cotton (Luttrell et al. 2015; Starr et al. 2007). Currently, the cotton industry faces major challenges to manage emerging pests such as plant-parasitic nematodes (Robinson 2008; Weaver 2015) and insects (Huseth et al. 2016; Luttrell et al. 2015; Perera et al. 2015).

Cotton is attacked by several species of plant-parasitic nematodes. The southern root-knot nematode (Meloidogyne incognita Kofoid \& White, 1919 Chitwood, 1949) and reniform nematode (Rotylenchulus reniformis Linford and Oliveira) cause the greatest damage to the crop (Lawrence et al. 2017); however, as suggested by research conducted on soybean, the latter may outcompete the former (Stetina et al. 1997). Over the past few years, reniform nematode has become predominant and the most important plantparasitic nematode of upland cotton in the southern United States (Robinson 2007; Starr et al. 2011; Stetina and Young 2006). Other nematode species known to damage cotton include Hoplolaimus, Belonolaimus, and Pratylenchus spp.; M. acronea Coetzee, 1956; M. enterolobii Yang and Eisenback, 1983; and Longidorus, Paratrichodorus, Scutellonema, and Xiphinema spp. (Robinson 2008; Ye et al. 2013).

\section{RENIFORM NEMATODE}

The reniform nematode was first observed in 1940 on the island of Oahu in Hawaii, parasitizing cowpea (Linford and Oliveira 1940). Reniform nematode is a sedentary semiendoparasite with more than 350 plant species representing 77 plant families as known hosts (Jones et al. 2013; Robinson et al. 1997). The nematode is distributed in both tropical and subtropical regions of the world (Jones et al. 2013). The genus Rotylenchulus consists of 10 previously described (Robinson et al. 1997) and one recently described (Van Den Berg et al. 2016) species. Of the 11 species of reniform nematode, only $R$. reniformis and $R$. parvus have been reported from the United States (Robinson 2008; Robinson et al. 1997). Upon infection, reniform nematode adversely affects plant growth, delays flowering and fruiting times, reduces the number and size of the bolls, and decreases lint quality (Robinson 2007). An illustration of the extent of damage that reniform nematode can cause on cotton early and late in the crop growing season is provided in Figures 1 and 2, respectively. Approximately 205,000 bales of cotton are lost to reniform nematode annually in the United States

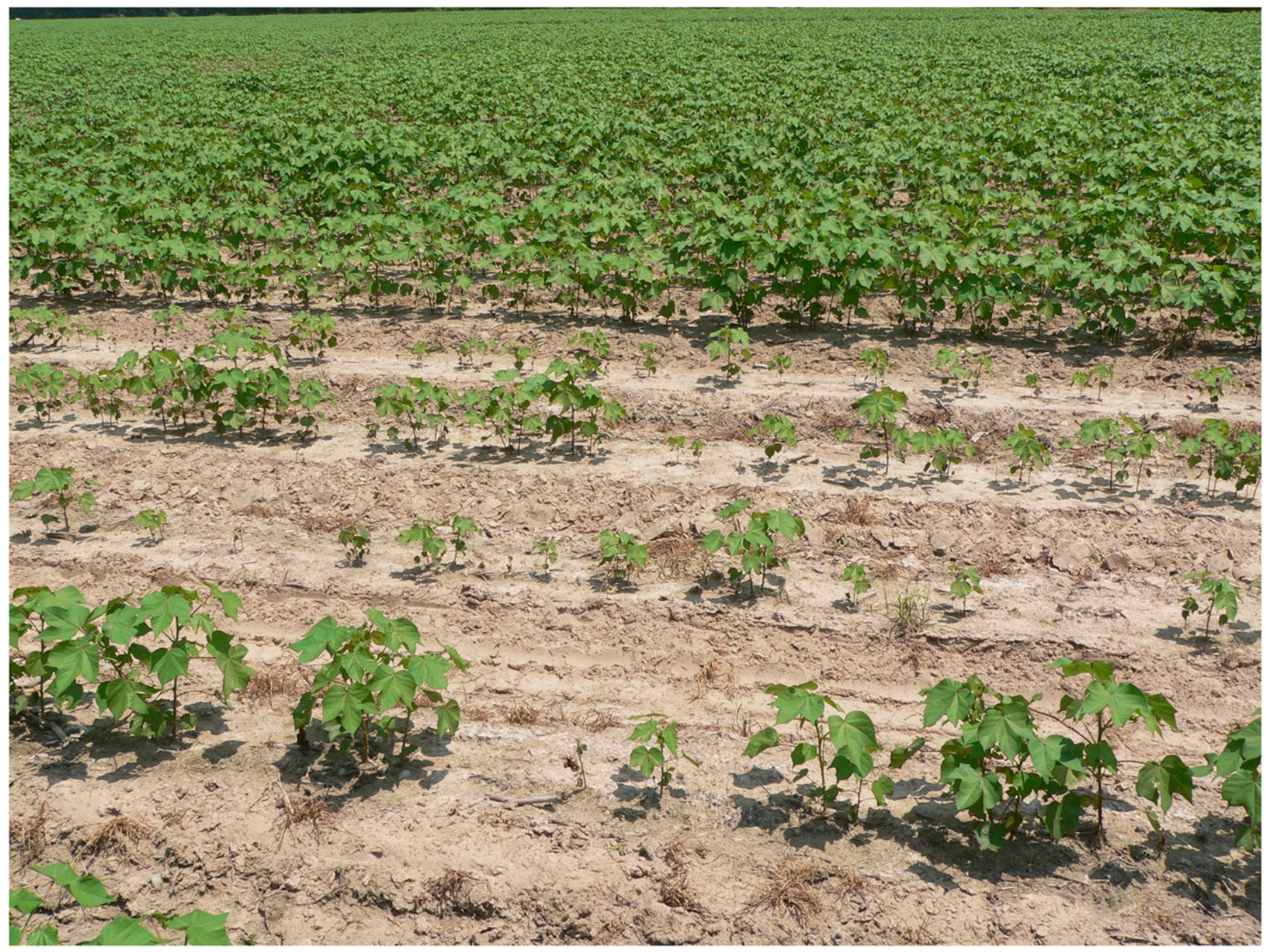

FIGURE 1

Cotton field showing a poor crop stand and dead plants resulting from reniform nematode infection early in the crop growing season. 
(Lawrence et al. 2017), which translates to roughly $11 \%$ of cotton losses attributed to all cotton diseases. Losses to reniform nematode in Louisiana, Mississippi, and Alabama in 2016 were 3, 4, and 5\%, respectively (Lawrence et al. 2017).

The damage threshold for reniform nematode is very low. As few as 2 reniform nematodes $/ \mathrm{cm}^{3}$ of soil early in the season is enough to elicit economic crop loss by the end of crop growing season (Weaver 2015). Similarly, a population density of only 10 nematodes $/ \mathrm{cm}^{3}$ of soil late in the season usually causes economic injury (Weaver 2015). Because of this low damage threshold, reniform nematode is listed as an A-rated pest in both California and Arizona. An A-rated pest is defined as a pest of pathogenic importance that is subject to regulations such as quarantine and eradication.

An overview of the life cycle of reniform nematode has been provided by Linford and Oliveira (1940) and Robinson et al. (1997). Briefly, the rear body portion of mature females that protrude from host root tissue contains eggs that are covered by a gelatinous substance secreted by the vaginal glands. Under favorable conditions, embryogenesis takes place and a first-stage juvenile is formed within the egg. After molting, the second-stage juvenile is formed and emerges from the egg shell. Subsequent growth and cuticle molts produce third- and fourth-stage juveniles. Fourth-stage juveniles develop further into males and vermiform females. Unlike most other phytoparasitic nematodes, where the second-stage juvenile is infective, the fourth-stage vermiform female of reniform nematode is infective. The infective female usually penetrates the root near the zone of elongation and feeds semiendoparasitically. As the female feeds on host cells, multinucleate syncytia are formed from which the female obtains the nutrition necessary for subsequent growth and maturation. The life cycle, relative to other plant-parasitic nematodes, is significantly shorter in duration, requiring 23 to 25 days under optimum conditions (Linford and Oliveira 1940). Additionally, reniform nematode has the unique and ecologically advantageous ability to enter a state of anhydrobiosis when conditions for growth and reproduction are unfavorable. Anhydrobiotic survival is achieved primarily by controlling water loss from the body and maintaining minimal metabolic activity (Birchfield and Martin 1967; Gaur and Perry 1991).

\section{CURRENTLY AVAILABLE MANAGEMENT METHODS AND THEIR LIMITATIONS}

Management options currently available for reniform nematode in upland cotton are chemicals, biological control, and crop rotation. The least-desirable but most commonly employed method of managing nematodes is the use of chemicals. Chemical nematicides currently available include those that are formulated as fumigants, nonfumigants, and seed treatments. Fumigants such as Telone have typically been the most effective in reducing populations of the nematode and giving the greatest yield increase.

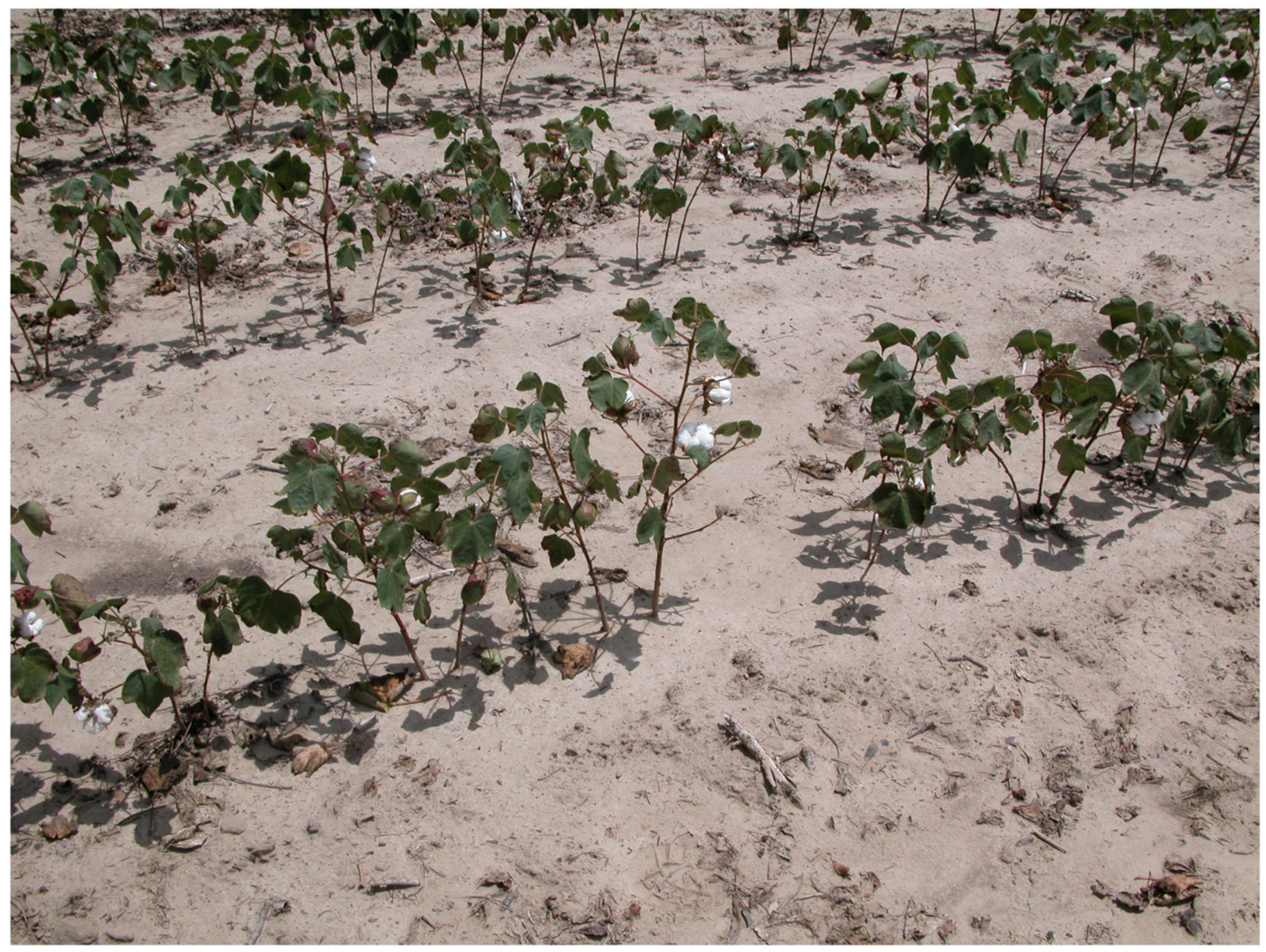

FIGURE 2

Cotton field showing stunted plants with very few bolls resulting from reniform nematode infection late in the crop growing season. 
Although reniform nematode is typically widespread within a field, changes within the soil texture in a field may influence where fumigants are most efficacious (Overstreet et al. 2014). Aldicarb, a nonfumigant, was the primary nematicide utilized in cotton production in the United States from the 1980s to 2010, when it was no longer produced. Although aldicarb has recently been introduced again, seed treatments now are the dominant nematicides utilized by producers. Seed treatments such as thiodicarb, abamectin, and, more recently, fluopyram (Faske and Hurd 2015; Faske and Starr 2006; Schrimsher et al. 2014) are popular because of the ease of application. A limitation of seed treatments is that efficacy occurs only when there are low to moderate populations of nematodes. Ironically, due to adverse effects of nematicides on human health and the environment, the use of chemicals is no longer the preferred method of management. Furthermore, reniform nematode can occur in the soil profile up to a depth of $122 \mathrm{~cm}$ (Robinson et al. 2005), which is beyond the effective depth of most chemicals (Weaver 2015).

Some bacteria and fungi have been used as biological control agents to manage reniform nematode. A Pasteuria sp. has been identified from $R$. reniformis and reported to be effective against this nematode under greenhouse conditions (Schmidt et al. 2010). Currently, several biocontrol agents are available in the market with the names Poncho/VOTiVO (Bacillus firmus) and NemOut or BioAct (Purpureocillium lilacinus). Biological organisms must compete with the existing microflora and microfauna present in the soil and results may not be consistent from one location to another. There have been only slight to moderate successes with biologicals in managing reniform nematode in cotton under field condition (Castillo et al. 2013; Faske et al. 2017).

In the past, crop rotation has been shown to be an effective management tool for reniform nematode. Crop rotation of 2 years of corn followed by 1 year of cotton has been found to be a useful strategy (Stetina et al. 2007). Some soybean cultivars that are resistant to reniform nematode are available (Robbins et al. 2015) and can also be used as a rotation crop (Davis et al. 2003). Selection of a rotation crop is mainly dictated by economic value of that crop. Therefore, a good rotation crop might not be a desirable crop for farmers. Additionally, when a susceptible crop is planted followed by a nonhost crop, the reniform nematode population rebounds quickly and reaches damaging levels in a single crop growing season (Robinson et al. 2007; Westphal and Smart 2003). An additional problem with crop rotation is the weed hosts that may develop after crop maturity. In the lower South, crops such as corn or soybean may be harvested in August, leaving 2 to 3 months for weeds to develop. Many of the dicotyledonous weed species found in a cotton-corn rotation have been found to be hosts of $R$. reniformis (Lawrence et al. 2008; Molin and Stetina 2016).

Reniform nematode management options currently available to use in cotton production, as described above, have several drawbacks. Scientists have always been looking for a safer, more effective, and durable method of management of reniform nematode. Utilization of host plant resistance has been a success in managing several plant pathogens (Jayavalli et al. 2015; Jo et al. 2014; Sharma et al. 2012; Singh et al. 2011; Zhan et al. 2012). Host plant resistance can be utilized as a cost-effective, health- and environment-friendly, and reliable method of reniform nematode management in cotton.

\section{HOST PLANT RESISTANCE}

Resistant cultivars represent the most desirable and cost-effective method of managing pathogens. This section provides a brief history, summary of current conditions, and probable future research directions to identify and employ host plant resistance from two perspectives: conventional breeding activities and molecular approaches.
Breeding activities. The screening of reniform nematoderesistant upland cotton cultivars was started in the early 1960s. A greenhouse study by Birchfield and Brister (1963) found that, of 24 upland cotton cultivars tested, none were resistant to reniform nematode. More than five decades have passed since this work but reniform nematode-resistant upland cotton cultivars are still not available today.

The assessment of host status for reniform nematode resistance is still conducted according to the scale proposed by Yik and Birchfield (1984), based on egg production per gram of root and expressed as percentage of eggs per gram of root on susceptible check. This scale contains the following classes: $0 \%=$ immune, 1 to $10 \%=$ highly resistant, 11 to $25 \%=$ resistant, 26 to $40 \%=$ moderately resistant, 41 to $100 \%=$ susceptible, and more than $100 \%=$ very susceptible. As an example, egg production on G. thurberi 'Todaro' and G. armourianum 'Kearney' was 36 and $122 \%$, respectively, of that on G. hirsutum 'Deltapine 16', rendering them moderately resistant and highly susceptible, respectively.

Evaluation of commercial upland cotton cultivars and germplasm lines against reniform nematode has led to the identification of some cultivars or lines with some resistance, although not at a satisfactory level. More than 2,000 upland cotton germplasm lines have been evaluated against reniform nematode and approximately 15 were moderately resistant; however, none were found to be highly resistant to reniform nematode (Robinson and Percival 1997; Robinson et al. 2004; Weaver et al. 2007; Yik and Birchfield 1984). Robinson et al. (2004) found that T2468 (PI 607773), a photoperiodic germplasm line collected from Brazil in 1988, was moderately resistant to reniform nematode. This line was crossed with Deltapine 61 and three neutral and moderately resistant germplasm lines (MT2468 Ren1, MT2468 Ren2, and MT2468 Ren3) were developed (McCarty et al. 2012). Even with the moderately resistant cultivars or lines, results were inconsistent when tested across various geographic locations (Robinson et al. 1997, 2004; Yik and Birchfield 1984; Weaver et al. 2007), perhaps an indication of variation in pathogenicity among geographic isolates of the nematode (McGawley et al. 2010, 2011).

Screening of upland cotton cultivars was conducted in the past to identify tolerance to reniform nematode (Blessitt et al. 2012). According to the glossary of the plant-disease treatise of the National Academy of Science, the term "tolerance" can be defined as the ability of a host to produce satisfactory crop yields even when challenged by a level of infection that causes economic yield losses to other cultivars (Schafer 1971; Usery et al. 2005). Some tolerance has been reported in nine cultivars (Blessitt et al. 2012; Stetina et al. 2009) and 11 germplasm lines (Cook and Robinson 2005; Cook et al. 1997; Jones et al. 1988) of upland cotton. It is important to mention that tolerant cultivars cannot be a long-term solution to a reniform nematode problem, because they do nothing to reduce the nematode population (Blessitt et al. 2012; Weaver 2015).

Because resistance to reniform nematode was not available in upland cotton cultivars (Yik and Birchfield 1984), efforts were made to find other sources of resistance. Yik and Birchfield (1984) evaluated several germplasm accessions of other species of cotton against reniform nematode. They found that G. longicalyx Hutchinson and Lee was immune to reniform nematode while G. stocksii Masters, G. somalense (Gurke) Hutchinson, and G. barbadense 'Texas 110' showed high levels of resistance. Since then, research has been focused primarily on the introgression of reniform nematode resistance from other species of cotton into upland cotton cultivars.

Among the highly resistant Gossypium spp. of cotton identified by Yik and Birchfield (1984), G. barbadense, G. longicalyx, and G. aridum (Rose and Standley) Skovsted have been used to introgress resistance into upland cotton. G. barbadense and upland cotton are tetraploid species with genome AD. This makes it easy to introgress resistance from $G$. barbadense to upland cotton using 
conventional breeding methods. Yik and Birchfield (1984) reported that G. barbadense 'Texas 110' (PI 163608) suppressed 92\% of reniform nematode reproduction (eggs), making this accession highly resistant. In 2010, using G. barbadense 'Texas 110' as a source of resistance, two breeding lines, TAM RKRNR-9 (PI 662039) and TAM RKRNR-12 (PI 662040), were released by Texas Agrilife Research (Starr et al. 2011). These lines were moderately resistant to reniform nematode and were taller and later maturing than concurrent upland cotton cultivars grown in Texas (Starr et al. 2011). A different G. barbadense accession, GB-713 (PI 608139), was reported to suppress approximately $97 \%$ of reniform nematode reproduction (juveniles), indicating that this species is highly resistant (Robinson et al. 2004). Four germplasm lines-M713 Ren1 (PI 665928), M713 Ren2 (PI 665929), M713 Ren5 (PI 665930), and BARBREN-713 (PI 671965)—were developed with reniform nematode resistance derived from $G$. barbadense accession GB713 (Bell et al. 2015; McCarty et al. 2013). The lines M713 Ren1, M713 Ren2, and M713 Ren5 exhibited a high level of resistance in greenhouse experiments, whereas agronomic performance in winter nursery was not always superior to the cultivar SureGrow 747 (McCarty et al. 2013). McCarty et al. (2017) recently developed six germplasm lines-M Rk-Rn 1(PI 678938), M Rk-Rn 2 (PI 678939), M Rk-Rn 3 (PI 678940), M Rk-Rn 4 (PI 678941), M Rk-Rn 5 (PI 678942), and M Rk-Rn 6 (PI 78943)-having reniform nematode resistance derived from M713 Ren3 and reported that the lines significantly suppressed reniform nematode reproduction in growth-chamber tests. The germplasm line BARBREN-713 is an $\mathrm{F}_{4}$ progeny of plant 06:104-3:2 that was developed by crossing GB713 with upland cotton cultivars (Bell et al. 2015). The $F_{3}$ plants from the $\mathrm{F}_{2}$ progenitor of BARBREN-713, plant 06:104-3:2, reduced population of reniform nematode by $75 \%$ that of the susceptible cultivar Deltapine 16 in a reniform nematode-infested field in Mississippi (Bell et al. 2015). Evaluation of BARBREN-713 in reniform nematode-infested fields in Texas, Louisiana, and Alabama resulted in overall suppression of reniform nematode populations by 55\% (Bell et al. 2015). Wallace et al. (2013) found that yield performance of BARBREN-713 in fields of Alabama and Mississippi having moderate levels of initial reniform nematode population density (approximately 30,000 to 50,000 nematodes/ $500 \mathrm{~g}$ of soil) was superior to the four obsolete cultivars tested. The absence of a high level of resistance and inconsistencies in performance of BARBREN lines across geographic locations have been major constraints in the development of upland cotton cultivars with reniform nematode resistance derived from G. barbadense.

In contrast to the high level of resistance in G. barbadense, G. longicalyx is immune to reniform nematode (Yik and Birchfield 1984), meaning that this species supports no reproduction of reniform nematode. This is why G. barbadense was not the first choice of scientists to introgress reniform nematode resistance into upland cotton. Rather, scientists were primarily interested to introgress resistance from $G$. longicalyx into upland cotton cultivars. G. longicalyx is a diploid species with the F genome. Because of this difference in ploidy level and genome, genetic incompatibility comes into play and results in infertile or male sterile progeny when crossed with upland cotton. To overcome the genetic incompatibility brought by ploidy level difference, scientists devised a unique approach known as "triple species hybrid". Details of the triple species hybrid cross have been described by Bell and Robinson (2004) and Konan et al. (2007). Briefly, a tetraploid cotton plant was crossed with a diploid cotton plant. This crossing gave rise to a triploid plant which was infertile. Colchicine treatment was employed with meristematic tissue of the triploid plant to double the chromosome number, giving rise to a hexaploid plant. Thus obtained, the hexaploid plant was, in turn, crossed with another diploid plant, producing a fertile tetraploid plant. G. hirsutum $\times$ G. longicalyx $\times$ G. armourianum $(\mathrm{HLA})$, G. hirsutum $\times$
G. herbaceum $\times$ G. longicalyx $(\mathrm{HHL})$, and $G$. hirsutum $\times$ G. thurberi $\times$ G. longicalyx (HTL) hybrids have been developed using the strategy of triple species hybrid. According to Bell and Robinson (2004), a value of $1 \%$ of the nematodes observed either in soil or on roots of the susceptible check at the end of a resistance assay can be technically defined as immunity because a small number of the nematodes from primary inoculum usually survive until termination of the experiment. The number of reniform nematode in roots of HLA, HHL, and HTL hybrid was less than $1 \%$ of the susceptible check (Bell and Robinson 2004; Konan et al. 2007) suggesting that these hybrids are virtually immune to reniform nematode. Scientists have repeatedly backcrossed these hybrids with upland cotton cultivars to develop reniform nematode-resistant upland cotton breeding lines.

In 2007, the United States Department of Agriculture-Agricultural Research Service, Texas Agricultural Experiment Station, and Cotton Incorporated released two reniform nematode-resistant breeding lines, LONREN-1 (PI 669509) and LONREN-2 (PI 669510), that were derived from the HLA hybrid and have a resistance gene introgressed from G. longicalyx (Bell et al. 2014). These breeding lines, however, are not as effective as their source of resistance in suppressing the reniform nematode reproduction. When the breeding lines were evaluated under a controlled environment in a growth chamber, they suppressed reniform nematode reproduction by $95 \%$ or more (Bell et al. 2014). The LONREN breeding lines were evaluated from 2008 to 2010 in fields of Louisiana and Texas having high initial population densities of reniform nematode (Bell et al. 2014). Suppression of reniform nematode reproduction in the fields of Louisiana and Texas was up to 80 and $50 \%$, respectively (Bell et al. 2014). At both locations, early-season stunting of LONREN lines was observed and resulted in a yield losses of 30 to $40 \%$ (Bell et al. 2014). However, when the LONREN lines were grown in fields with low reniform nematode population densities, stunting and crop yield losses were not observed (Bell et al. 2014). Results indicate that LONREN lines can perform better under low reniform nematode population density whereas the lines are intolerant to high nematode population density. According to Nichols et al. (2010), stunting of LONREN breeding lines under high reniform nematode population densities was possibly caused by linkage drag resulting from simultaneous introgression of unwanted genes from G. longicalyx.

Sikkens et al. (2011) conducted a greenhouse experiment to determine the influence of different levels of populations of the reniform nematode on LONREN lines during early-season plant growth. Inoculum levels used ranged from 0 to 50,000 juveniles and vermiform life stages of reniform nematode per $150 \mathrm{~cm}^{3}$ of soil. At 60 days after inoculation, dry root mass of the resistant breeding lines was found to decline with increasing inoculum density. An opposite trend was found with the susceptible genotypes; that is, dry root mass was increased with increasing levels of inoculum. Dry shoot mass of breeding lines and susceptible genotypes was largely unaffected at any level of inoculum except the highest. Sikkens et al. (2011) noticed that reduced shoot weight of the breeding lines was the consequence of reduced root weight. They went a step further and closely examined the root systems of each genotype tested. There was necrosis in the roots of the breeding lines that received the highest inoculum level, suggesting a hypersensitive response. This hypersensitive response reaction in breeding lines led to the reduced root mass and, ultimately, stunted plants.

Sacks and Robinson (2009) developed a different triple species hybrid by crossing highly resistant G. arboreum $\mathrm{A}_{2}-190$ (PI 615699 ) with G371, a hexaploid bridging line (G. hirsutum $\times$ G. aridum). A high level of resistance in bridging line G371 was transferred from G. aridum (Fang and Stetina 2011). Growthchamber tests conducted by Stetina and Erpelding (2016) evaluated 222 G. arboreum accessions from the United States germplasm collection and found that 10 accessions (PI 529992, PI 615755, PI 
615766, PI 615788, PI 615856, PI 615950, PI 615991, PI 616008, PI 616159, and PI 615848) suppressed $97 \%$ or greater reniform nematode population development compared with $G$. hirsutum 'Deltapine 16'. They also found that the accession PI 615848 supported less reniform nematode population development than the resistant control G. arboreum $\mathrm{A}_{2}-190$ (PI 615699). To our knowledge, any breeding lines conferring resistance derived from $G$. arboreum or $G$. aridum have not been released.

Molecular approach. Use of molecular techniques to develop reniform nematode-resistant upland cotton cultivars is a relatively new area of investigation. Excellent research has been conducted at the molecular level to facilitate development of reniform nematoderesistant upland cotton cultivars. The first step in a molecular approach is to identify genes conferring reniform resistance and their location on chromosomes. Thus far, six reniform nematode resistance genes ranging from dominant to partial dominant to recessive in action have been identified in other species of cotton. $\operatorname{Ren}^{\text {lon }}$ and $\mathrm{Ren}^{\text {ari }}$ genes are dominant and identified in G. longicalyx on chromosome 11 and G. aridum on chromosome 21, respectively (Dighe et al. 2009; Romano et al. 2009). Ren ${ }^{\text {barb1 }}$, Ren ${ }^{\text {barb2 }}$, and $R_{e n}{ }^{\text {barb3 }}$ are partially resistant and identified in G. barbadense located on chromosomes 21, 21, and 18, respectively (Gutiérrez et al. 2011). Similarly, a recessive, unnamed gene conferring resistance to reniform nematode has been identified in G. arboreum L. (Erpelding and Stetina 2013). With the exception of the recessive gene, markers have been developed for all five reported genes. Recently, 10 of 222 accessions of G. arboreum were shown to have a high level of resistance to reniform nematode; however, the mode of action and exact location of genes conferring resistance is still unknown (Stetina and Erpelding 2016). Identification of molecular markers can expedite the process of selection of lines or cultivars that have the resistance genes introgressed. Utilization of a markerassisted selection (MAS) method has been found to be very useful in screening root-knot nematode resistance in cotton (Jenkins et al. 2012). Cotton breeders are working diligently to introgress identified reniform nematode resistance genes into upland cotton by utilizing the MAS method.

Reniform nematode-resistant upland cotton cultivars can also be developed by transgenics. This technique, for example, could be employed by induction of protease (sometimes referred as proteinase) inhibitors into plants, or by silencing genes of interest. Some common protease inhibitors found in plants are cysteine-, serine-, aspartyl-, and metallo-protease inhibitors that are expressed in aerial plant parts and storage organs in a low concentrations in response to insect or pathogen attack (Atkinson et al. 2003; Peng and Black 1976; Ryan 1990). Some mechanisms of action of protease inhibitors include inhibition of the development and fecundity of nematode females (Atkinson et al. 2003). This approach has been tested with root-knot nematode and soybean cyst nematode using Arabidopsis thaliana that was engineered to express cysteine protease inhibitor (Urwin et al. 1995, 1997). Results showed that the nematodes lost cysteine protease activity in the intestine, leading to significant reduction in the size and fecundity of females. A study conducted by Urwin et al. (2000) found that $A$. thaliana plants expressing a cysteine protease inhibitor was effective in reducing approximately 65 and $30 \%$ reproduction and fecundity, respectively, of reniform nematode. Though more research is required, transgenic cotton plants expressing protease inhibitors in roots at higher concentrations could be very useful in managing reniform nematode.

A promising and emerging field of biological science for management of plant pathogens is gene silencing. Gene silencing, also known as RNA interference (RNAi), is considered to be the oldest defense mechanism employed by eukaryotes to combat viruses (Sharp 2001). Several genes have been silenced in the freeliving nematode Caenorhabditis elegans using this technique (Fire et al. 1991, 1998). Parrish et al. (2000) delivered double-stranded
RNA (dsRNA) in C. elegans and found that the dsRNA was cleaved into short interfering RNA (siRNA) of 21 to 23 nucleotides. Subsequent experimentation led to the discovery that the cleavage of dsRNA into siRNA is mediated by a host protein called dicer (Nunes and Dean 2012). The siRNA, in turn, form a silencing complex with other proteins that cleave complementary mRNA sequences in the host, leading to gene silencing (Elbashir et al. 2001; Hammond et al. 2000; Nunes and Dean 2012; Sharp 2001; Zamore et al. 2000). This method of dsRNA delivery in free-living nematodes cannot be applied to plant-parasitic nematodes because of the difference in their feeding behavior. Because free-living nematodes ingest food directly from a solution, it is easy to deliver dsRNA simply by immersing nematodes in a solution containing dsRNA. In contrast, plant-parasitic nematodes use the protractible stylet to puncture host cells, deliver pathogenesis-related enzymes to the host, and withdraw cytoplasmic contents. In order for gene silencing to work with plant-parasitic nematodes, it would be necessary to develop transgenic cotton plants that can synthesize specific dsRNA that is deliverable to the nematode body during infection. The gene-silencing approach has been tested with M. incognita and the cyst nematodes Globodera pallida and Heterodera glycines in vitro, although with varying levels of success (Rosso et al. 2005; Urwin et al. 2002). Such laboratory assays have been performed by dipping second-stage juveniles in a solution containing dsRNA. To date, there are no published reports of the application of the RNAi approach with reniform nematode.

Prior to conducting gene-silencing assays, it is necessary to identify the candidate genes for pathogenesis. To date, some putative genes for pathogenesis have been identified in root-knot and cyst nematodes (Cai et al. 1997; Dubreuil et al. 2009; Fairbairn et al. 2007; Huang et al. 2006; Urwin et al. 2002). Most of the research on gene silencing in nematodes has concentrated on root-knot and cyst nematodes. It is certainly possible that reniform and other nematodes share some homology in parasitism genes. Therefore, research on identification of parasitism genes in any nematode can have applicability to reniform nematode as well. Once pathogenesis genes are identified in nematodes, the next logical step would be to optimize a gene-silencing assay in planta. With the continual advancement in biotechnology it is probable that the genesilencing approach may be utilized to manage reniform nematode in the next decade.

It is unfortunate that attempts to transfer immunity to reniform nematode present in G. longicalyx into upland cotton also led to the development of LONREN breeding lines that exhibit stunting symptoms in the presence of high populations of $R$. reniformis. A possible explanation for such stunting is the linkage drag caused by cointrogression of segments from alien chromosomes with nonbeneficial genes (Nichols et al. 2010). Utilization of precise genome editing tools currently available would be useful for delivery of reniform nematode resistance genes while avoiding any unwanted genes. Recent molecular techniques such as zinc-finger nuclease (ZFN), transcription activator-like effector nuclease (TALEN), and clustered regularly interspaced short palindromic repeat (CRISPR)Cas9 systems have been employed for precise genome editing in C. elegans and other eukaryotic organisms (Bassett et al. 2013; Burle-Caldas et al. 2017; Cho et al. 2013; Friedland et al. 2013; Kim et al. 2014; Schneider et al. 2016, Takasu et al. 2016, Wood et al. 2011). Once the nucleotide sequences coding for reniform nematode resistance gene are available, it would be possible to perform precise introgression of the reniform nematode resistance in upland cotton.

To develop a suitable management strategy, it is extremely important to understand the feeding behavior of the nematode. A detailed understanding of the exact enzymes that are delivered by the nematode to induce syncytia in the host and how, exactly, the nematode utilizes host cell assimilate is unclear. Reports suggest that plant-parasitic nematodes, including reniform nematode, form 
blind-ended feeding tubes at the stylet orifice and within the cytoplasm of the plant cell that facilitate withdrawal of host cell assimilate (Eves-van den Akker et al. 2014; Razak and Evans 1976; Sobczak et al. 1999). Razak and Evans (1976) hypothesized that these feeding tubes serve as a molecular sieve that allows only appropriatesized proteins to enter the stylet and, ultimately, nematode body. As an example, the sugarbeet cyst nematode $H$. schachtii excludes dextrans of 40 but not $22 \mathrm{kDa}$ expressed in genetically engineered $A$. thaliana (Böckenhoff and Grundler 1994). It is possible that such feeding tubes were formed by endoparasitic nematodes during evolutionary development in order to exclude lethal proteins or molecules. This ultrafiltration strategy of nematodes employing feeding tubes suggests that small-sized proteins or effectors that are lethal to nematodes could possibly be ingested by the nematode if it fed on a genetically engineered host plant. However, the exact size exclusion limit of such proteins by feeding tubes is unknown. Delivery of appropriate size lethal proteins such as the "cry" protein to the nematode body would be useful in managing plant-parasitic nematodes. The cry proteins are of an insecticidal nature and are produced by $B$. thuringiensis bacteria during the sporulation phase (Bravo et al. 2007). Marroquin et al. (2000) showed that the oral uptake of a $140-\mathrm{kDa}$ Cry5B protein was lethal to C. elegans. However, as described earlier, plant-parasitic nematodes can exclude even 40-kDa proteins; thus, effector proteins of less than $40 \mathrm{kDa}$ may be deliverable to plant-parasitic nematodes. The possibility that these small proteins could be used to manage reniform nematode in upland cotton is still a long way off.

\section{SUMMARY AND FUTURE OUTLOOK}

The reniform nematode has emerged as one of the major constraints of upland cotton production. A significant amount of crop yield is lost due to reniform nematode every year. The annual United States cotton yield losses by reniform nematode is estimated to exceed 205 million bales, accounting for $31 \%$ of the loss to all nematodes (Lawrence et al. 2017). Current management methods are primarily based on chemicals and crop rotation because of the unavailability of reniform nematode-resistant upland cotton cultivars. The use of nematicides is no longer the preferred method of management because of their adverse effects on human health and the environment. Crop rotation with nonhosts such as corn and sorghum is effective in reducing reniform nematode populations significantly. However, the reniform nematode populations usually resurge quickly to a damaging level in a single year of cotton production (Robinson et al. 2007; Westphal and Smart 2003).

The most desirable and environmentally responsible method of reniform nematode management in cotton is use of resistant cultivars. Hope emerged after the problem of genetic incompatibility between genetically different resistant and susceptible species was solved using a triple species hybrid. Unfortunately, to date, the development of reniform nematode-resistant plants has been limited to breeding lines only. Breeding lines with reniform nematode resistance derived from $G$. barbadense lack a high level of resistance and their yield performance across geographic locations is inconsistent (Sikkens et al. 2012). Other breeding lines having resistance derived from $G$. longicalyx develop stunting under high reniform nematode population density (Nichols et al. 2010; Sikkens et al. 2011). In general, the stunting related to G. longicalyx is the reason that this species has largely been abandoned by cotton breeders. Current breeding efforts to develop upland cotton cultivars with satisfactory levels of reniform nematode resistance are based on employment of resistance in BARBREN lines.

Despite the intense efforts of researchers, reniform nematoderesistant upland cotton cultivars are still unavailable. Unavailability of resistance to the reniform nematode within $G$. hirsutum is one of the major limiting factors of upland cotton production in the United States (Robinson et al. 1999, 2007). The development of reniform nematode-resistant upland cotton cultivars using only conventional breeding methods will take many more years. Molecular techniques coupled with the breeding methods will likely lead to the development of resistant upland cotton cultivars. Some genes and locations on chromosomes that confer reniform nematode resistance have been identified in other species of cotton (Dighe et al. 2009; Gutiérrez et al. 2011; Romano et al. 2009). Introgression and pyramiding of these genes into upland cotton cultivars can hopefully provide a durable resistance. However, gene transfer techniques frequently lead to cointrogression of undesirable chromosomal segments producing undesirable traits. Cutting-edge molecular techniques such as ZFN, TALEN, and CRISPR-Cas9 systems can be employed for precise genome editing for reniform nematode resistance in cotton. Expression of cry proteins and protease inhibitors in upland cotton would help manage reniform nematode in the future. Similarly, the utilization of MAS can expedite the process of identification of resistant lines in both conventional and molecular breeding programs. We believe that, with the amalgamation of conventional breeding and cutting-edge molecular techniques, the long-term breeding objective of developing reniform nematode-resistant upland cotton cultivars will be achieved.

\section{ACKNOWLEDGMENTS}

We thank B. McInnes and M. Kularathna for providing critical reviews of this manuscript. Mention of trade names or commercial products is solely for the purpose of providing specific information and does not imply recommendation or endorsement by Louisiana State University (LSU) and the United States Department of Agriculture (USDA). LSU and USDA are equal opportunity providers and employers.

\section{LITERATURE CITED}

Anonymous. 2010. Field Crops Usual Planting and Harvesting Dates. Online publication. United States Department of Agriculture-National Agricultural Statistics Service. http://usda.mannlib.cornell.edu/usda/current/planting/ planting-10-29-2010.pdf

Anonymous. 2017. Crop Production 2016 Summary. Online publication. United States Department of Agriculture-National Agricultural Statistics Service. http://usda.mannlib.cornell.edu/usda/nass/CropProdSu//2010s/2017/CropProdSu01-12-2017.pdf

Atkinson, H. J., Urwin, P. E., and McPherson, M. J. 2003. Engineering plants for nematode resistance. Annu. Rev. Phytopathol. 41:615-639.

Bassett, A. R., Tibbit, C., Ponting, C. P., and Liu, J.-L. 2013. Highly efficient targeted mutagenesis of Drosophila with the CRISPR/Cas9 system. Cell Rep. 4:220-228.

Bell, A., and Robinson, A. F. 2004. Development and characteristics of triple species hybrids used to transfer reniform nematode resistance from Gossypium longicalyx to Gossypium hirsutum. Pages 422-426 in: Proc. Beltwide Cotton Conf. San Antonio, TX.

Bell, A. A., Robinson, A. F., Quintana, J., Dighe, N. D., Menz, M. A., Stelly, D. M., Zheng, X., Jones, J. E., Overstreet, C., Burris, E., Cantrell, R. G., and Nichols, R. L. 2014. Registration of LONREN-1 and LONREN-2 germplasm lines of upland cotton resistant to reniform nematode. J. Plant Regist. 8:187-190.

Bell, A. A., Robinson, A. F., Quintana, J., Duke, S. E., Starr, J. L., Stelly, D. M., Zheng, X., Prom, S., Saladino, V., Gutiérrez, O. A., Stetina, S. R., and Nichols, R. L. 2015. Registration of BARBREN-713 germplasm line of upland cotton resistant to reniform and root-knot nematodes. J. Plant Regist. 9:89-93.

Birchfield, W., and Brister, L. R. 1963. Susceptibility of cotton and relatives to reniform nematode in Louisiana. Plant Dis. Rep. 47:990-992.

Birchfield, W., and Martin, W. J. 1967. Reniform nematode survival in airdried soil. (Abstr.) Phytopathology 57:804.

Blessitt, J. A., Stetina, S. R., Wallace, T. P., Smith, P. T., and Sciumbato, G. L. 2012. Cotton (Gossypium hirsutum) cultivars exhibiting tolerance to the reniform nematode (Rotylenchulus reniformis). Int. J. Agron. Article ID 893178. doi.org/10.1155/2012/893178

Böckenhoff, A., and Grundler, F. M. W. 1994. Studies on the nutrient-uptake by the beet cyst-nematode Heterodera schachtii by in situ microinjection of fluorescent probes into the feeding structures in Arabidopsis thaliana. Parasitology 109:249-255. 
Bravo, A., Gill, S. S., and Soberón, M. 2007. Mode of action of Bacillus thuringiensis Cry and Cyt toxins and their potential for insect control. Toxicon 49:423-435.

Burle-Caldas, G. A., Grazielle-Silva, V., Soares-Simões, M., Burkard, G. S., Roditi, I., DaRocha, W. D., and Teixeira, S. M. 2017. Editing the Trypanosoma cruzi genome with zinc finger nucleases. Mol. Biochem. Parasitol. 212:28-32

Cai, D. G., Kleine, M., Kifle, S., Harloff, H. J., and Sandal, N. N. 1997. Positional cloning of a gene for nematode resistance in sugar beet. Science 275:832-834.

Castillo, J. D., Lawrence, K. S., and Kloepper, J. W. 2013. Biocontrol of the reniform nematode by Bacillus firmus GB-126 and Paecilomyces lilacinus 251 on cotton. Plant Dis. 97:967-976.

Cho, S. W., Kim, S., Kim, J. M., and Kim, J. S. 2013. Targeted genome engineering in human cells with the Cas9 RNA-guided endonuclease. Nat. Biotechnol. 31:230-232.

Cook, C. G., Namken, L. N., and Robinson, A. F. 1997. Registration of N2201-91, N222-1-01, N320-2-91, and N419-1-91 nematode-resistant cotton germplasm lines. Crop Sci. 37:1028-1029.

Cook, C. G., and Robinson, A. F. 2005. Registration of RN96425, RN96527, and RN96625-1 nematode-resistant cotton germplasm lines. Crop Sci. 45: 1667-1668.

Dabbert, T. A., and Gore, M. A. 2014. Challenges and perspectives on improving heat and drought stress resilience in cotton. J. Cotton Sci. 18:393-409.

Davis, R. F., Koenning, S. R., Kamerait, R. C., Cummings, T. D., and Shurley, W. D. 2003. Rotylenchulus reniformis management in cotton with crop rotation. J. Nematol. 35:58-64.

Dighe, N. D., Robinson, A. F., Bell, A. A., Menz, M. A., Cantrell, R. G., and Stelly, D. M. 2009. Linkage mapping of resistance to reniform nematode in cotton following introgression from G. longicalyx (Hutch. \& Lee). Crop Sci. 49:1151-1164.

Dubreuil, G., Magliano, M., Dubrana, M. P., Lozano, J., Lecomte, P., Favery, B., Abad, P., and Rosso, M. N. 2009. Tobacco rattle virus mediates gene silencing in a plant parasitic root-knot nematode. J. Exp. Bot. 60: 4041-4050.

Elbashir, S. M., Lendeckel, W., and Tuschl, T. 2001. RNA interference is mediated by 21-and 22-nucleotide RNAs. Genes Dev. 15:188-200.

Erpelding, J. E., and Stetina, S. R. 2013. Genetics of reniform nematode resistance in Gossypium arboreum germplasm line PI 529728. World J. Agric. Res. 1:48-53.

Eves-van den Akker, S., Lilley, C. J., Ault, J. R., Ashcroft, A. E., Jones, J. T., and Urwin, P. E. 2014. The feeding tube of cyst nematodes: Characterisation of protein exclusion. PLoS One 9:e87289.

Fairbairn, D. J., Cavallaro, A. S., Bernard, M., Mahalinga-Iyer, J., Graham, M. W., and Botella, J. R. 2007. Host-delivered RNAi: An effective strategy to silence genes in plant parasitic nematodes. Planta 226:1525-1533.

Fang, D. D., and Stetina, S. R. 2011. Improving cotton (Gossypium hirsutum L.) plant resistance to reniform nematodes by pyramiding $\operatorname{Ren}_{1}$ and $\operatorname{Ren}_{2}$. Plant Breed. 130:673-678.

Faske, T. R., Allen, T. W., Lawrence, G. W., Lawrence, K. S., Mehl, M. L., Norton, R., Overstreet, C., and Wheeler, T. A. 2017. Beltwide nematode research and education committee report on cotton cultivars and nematicides responses in nematode soils, 2016. Pages 270-273 in: Proc. Beltwide Cotton Conf. Dallas, TX.

Faske, T. R., and Hurd, K. 2015. Sensitivity of Meloidogyne incognita and Rotylenchulus reniformis to fluopyram. J. Nematol. 47:316-321.

Faske, T. R., and Starr, J. L. 2006. Sensitivity of Meloidogyne incognita and Rotylenchulus reniformis to abamectin. J. Nematol. 38:240-244.

Fire, A., Albertson, D., Harrison, S. W., and Moerman, D. G. 1991. Production of antisense RNA leads to effective and specific inhibition of gene expression in C. elegans muscle. Development 113:503-514.

Fire, A., Xu, S., Montgomery, M. K., Kostas, S. A., Driver, S. E., and Mello, C. C. 1998. Potent and specific genetic interference by double-stranded RNA in Caenorhabditis elegans. Nature 391:806-811.

Friedland, A. E., Tzur, Y. B., Esvelt, K. M., Colaiacovo, M. P., Church, G. M., and Calarco, J. A. 2013. Heritable genome editing in C. elegans via a CRISPR-Cas9 system. Nat. Methods 10:741-743.

Gaur, H. S., and Perry, R. N. 1991. The role of the moulted cuticles in the desiccation survival of adults of Rotylenchulus reniformis. Rev. Nematol. 14:491-496.

Gutiérrez, O. A., Robinson, A. F., Jenkins, J. N., McCarty, J. C., Wubben, M. J., Callahan, F. E., and Nichols, R. L. 2011. Identification of QTL regions and SSR markers associated with resistance to reniform nematode in Gossypium barbadense L. accession GB713. Theor. Appl. Genet. 122: 271-280.

Hammond, S. M., Bernstein, E., Beach, D., and Hannon, G. J. 2000. An RNAdirected nuclease cell mediates posttranscriptional gene silencing in Drosophila. Nature 404:293-296.
Huang, G., Allen, R., Davis, E. L., Baum, T. J., and Hussey, R. S. 2006. Engineering broad root-knot resistance in transgenic plants by RNAi silencing of a conserved and essential root-knot nematode parasitism gene. Proc. Natl. Acad. Sci. USA 103:14302-14306.

Huseth, A. S., Chappell, T. M., Langdon, K., Morsello, S. C., Martin, S., Greene, J. K., Herbert, A., Jacobson, A. L., Reay-Jones, F. P. F., Reed, T., Reisig, D. D., Roberts, P. M., Smith, R., and Kennedy, G. G. 2016. Frankliniella fusca resistance to neonicotinoid insecticides: An emerging challenge for cotton pest management in the eastern United States. Pest Manage. Sci. 72:1934-1945.

Jayavalli, R., Balamohanb, T. N., Manivannanc, N., Rabindrand, R., Paramagurue, P., and Robin, R. 2015. Transmission of resistance to papaya ringspot virus (PRSV) in intergeneric populations of Carica papaya and Vasconcellea cauliflora. Sci. Hortic. (Amsterdam) 187:10-14.

Jenkins, J. N., McCarty, J. C., Wubben, M. J., Hayes, R., Gutierrez, O. A., Callahan, F., and Deng, D. 2012. SSR markers for marker assisted selection of root-knot nematode (Meloidogyne incognita) resistant plants in cotton (Gossypium hirsutum L). Euphytica 183:49-54.

Jo, K. R., Kim, C. J., Kim, S. J., Kim, T. Y., Bergervoet, M., Jongsma, M. A., Visser, R. G. F., Jacobsen, E., and Vossen, J. H. 2014. Development of late blight resistant potatoes by cisgene stacking. BMC Biotechnol. 14:50.

Jones, J. E., Beasley, J. P., Dickson, J. I., and Caldwell, W. D. 1988. Registration of four cotton germplasm lines with resistance to reniform and rootknot nematodes. Crop Sci. 28:199-200.

Jones, J. T., Haegeman, A., Danchin, E. G. J., Gaur, H. R., Helder, J., Jones, M. G. K., Kikuchi, T., Manzanilla-Lopez, R., Palomares-Rius, J. E., Wesemael, W. M. L., and Perry, R. N. 2013. Top 10 plant-parasitic nematodes in molecular plant pathology. Mol. Plant Pathol. 14:946-961.

Kim, H., Ishidate, T., Ghanta, K. S., Seth, M., Conte, D., Jr., Shirayama, M., and Mello, C. C. 2014. A Co-CRISPR strategy for efficient genome editing in Caenorhabditis elegans. Genetics 197:1069-1080.

Koenning, S. R., Kirkpatrick, T. L., Starr, J. L., Wrather, J. A., Walker, N. R., and Mueller, J. D. 2004. Plant-parasitic nematodes attacking cotton in the United States: Old and emerging challenges. Plant Dis. 88:100-113.

Konan, N. O., Hont, A. D., Rodier-Goud, M., Baudoin, J. P., and Mergeai, G. G. 2007. Production of new cotton interspecific hybrids highly resistant to the reniform nematode. Proc. World Cotton Res. Conf. 4, Lubbock, TX. http://wcrc.confex.com/wcrc/2007/techprogram/P1190.HTM

Lawrence, K., Hagan, A., Norton, R., Faske, T., Hutmacher, R., Mueller, J., Wright, D., Small, I., Kemerait, B., Overstreet, C., Price, P., Lawrence, G., Allen, T., Atwell, S., Jones, A., Thomas, S., Goldberg, N., Boman, R., Goodson, J., Kelly, H., Woodward, J., and Mehl, H. L. 2017. Cotton disease loss estimate committee report, 2016. Pages 150-152 in: Proc. Beltwide Cotton Conf. Dallas, TX.

Lawrence, K. S., Price, A. J., Lawrence, G. W., Jones, J. R., and Akridge, J. R. 2008. Weed host for Rotylenchulus reniformis in cotton fields rotated with corn in the southeast United States. Nematropica 38:13-22.

Linford, M. B., and Oliveira, J. M. 1940. Rotylenchulus reniformis, nov. gen., n sp., a nematode parasite of roots. Proc. Helminthol. Soc. 7:35-42.

Luttrell, R. G., Teague, T. G., and Brewer, M. J. 2015. Cotton insect pest management. Pages 509-546 in: Cotton. D. D. Fang and R. C. Percy, eds. American Society of Agronomy, Madison, WI.

Marroquin, L. D., Elyassnia, D., Griffitts, J. S., Feitelson, J. S., and Aroian, R. V. 2000. Bacillus thuringiensis (Bt) toxin susceptibility and isolation of resistance mutants in the nematode Caenorhabditis elegans. Genetics 155: 1693-99.

Mauney, J. R., and Stewart, J. M. 1986. Cotton Physiology: The Cotton Foundation Reference Book Series. The Cotton Foundation, Memphis, TN.

McCarty, J. C., Jr., Jenkins, J. N., Wubben, M. J., Gutierrez, O. A., Hayes, R. W., Callahan, F. E., and Deng, D. 2013. Registration of three germplasm lines of cotton derived from Gossypium barbadense L. accession GB713 with resistance to the reniform nematode. J. Plant Regist. 7:220-223.

McCarty, J. C., Jr., Jenkins, J. N., Wubben, M. J., Hayes, R. W., Callahan, F. E., and Deng, D. 2017. Registration of six germplasm lines of cotton with resistance to root-knot and reniform nematodes. J. Plant Regist. 11:168-171.

McCarty, J. C., Jenkins, J. N., Wubben, M. J., Hayes, R. W., and LaFoe, J. M. 2012. Registration of three germplasm lines of cotton derived from Gossypium hirsutum L. accession T2468 with moderate resistance to the reniform nematode. J. Plant Regist. 6:85-87.

McGawley, E. C., Overstreet, C., and Pontif, M. J. 2011. Variation in reproduction and pathogenicity of geographic isolates of Rotylenchulus reniformis on soybean. Nematropica 41:12-22.

McGawley, E. C., Pontif, M. J., and Overstreet, C. 2010. Variation in reproduction and pathogenicity of geographic isolates of Rotylenchulus reniformis on cotton. Nematropica 40:275-288.

Meyer, L. 2017. Cotton and Wool Outlook. Online publication. United States Department of Agriculture, Economic Research Service. https://www.ers. usda.gov/webdocs/publications/84692/cws-17h.pdf?v=42961 
Meyer, L., and MacDonald, S. 2016. Cotton and Wool Outlook. Online publication. United States Department of Agriculture, Economic Research Service. http://usda.mannlib.cornell.edu/usda/ers/CWS//2010s/2016/CWS09-14-2016.pdf

Molin, W. T., and Stetina, S. R. 2016. Weed hosts and relative weed and cover crop susceptibility to Rotylenchulus reniformis in the Mississippi Delta. Nematropica 46:121-131.

Nichols, R. L., Bell, A., Stelly, D., Dighe, N., Robinson, F., Menz, M., Starr, J., Agudelo, P., Jones, J., Overstreet, C., Burris, E., Cook, C., Lemon, R., and Fang, D. 2010. Phenotypic and genetic evaluation of LONREN germplasm. Pages 798-799 in: Proc. Beltwide Cotton Conf. New Orleans, LA.

Nunes, C. C., and Dean, R. A. 2012. Host-induced gene silencing: A tool for understanding fungal host interaction and for developing novel disease control strategies. Mol. Plant Pathol. 13:519-529.

Overstreet, C., McGawley, E. C., Khalilian, A., Kirkpatrick, T. L., Monfort, W. S., Henderson, W., and Mueller, J. D. 2014. Site specific nematode management- development and success in cotton production in the U.S. J. Nematol. 46:309-320.

Parrish, S., Fleenor, J., Xu, S., Mello, C., and Fire, A. 2000. Functional anatomy of a dsRNA trigger: Differential requirement for the two trigger strands in RNA interference. Mol. Cell 6:1077-1087.

Peng, J. H., and Black, L. L. 1976. Increased proteinase inhibitor activity in response to infection of resistant tomato plants by Phytophthora infestans. Phytopathology 66:958-963.

Perera, O. P., Gore, J., Snodgrass, G. L., Jackson, R. E., Allen, K. C., Abel, K. A., and Luttrell, R. G. 2015. Temporal and spatial genetic variability among tarnished plant bug (Hemiptera: Miridae) populations in a small geographic area. Ann. Entomol. Soc. Am. 108:181-192.

Razak, A. R., and Evans, A. A. F. 1976. An intracellular tube associated with feeding by Rotylenchulus reniformis on cowpea root. Nematologica 22:182-189.

Robbins, R. T., Fallen, B., Shannon, G., Chen, P., Kantartza, S. K., Faske, T. R., Jackson, L. E., Grub, E. E., Dombek, D. G., Velie, J. T., and Arelli, P. 2015. Reniform nematode reproduction on Soybean cultivars and breeding lines in 2014. Pages 201-214 in: Proc. Beltwide Cotton Conf. San Antonio, TX.

Robinson, A. F. 2007. Reniform in U.S. cotton: When, where, why, and some remedies. Annu. Rev. Phytopathol. 45:263-288.

Robinson, A. F. 2008. Nematode management in cotton. Pages 149-182 in: Integrated Management and Biocontrol of Vegetable and Grain Crops Nematodes. A. Ciancio and K. G. Mukerji, eds. Springer, New York.

Robinson, A. F., Akridge, R., Bradford, J. M., Cook, C. G., Gazaway, W. S., Kirkpatrick, T. L., Lawrence, G. W., Lee, G., McGawley, E. C., Overstreet, C., Padgett, B., Rodriguez-Kabana, R., Westphal, A., and Young, L. D. 2005. Vertical distribution of Rotylenchulus reniformis in cotton fields. J. Nematol. 37:265-271

Robinson, A. F., Bell, A. A., Dighe, N. D., Menz, M. A., Nichols, R. L., and Stelly, D. M. 2007. Introgression of resistance to nematode Rotylenchulus reniformis into upland cotton (Gossypium hirsutum) from Gossypium longicalyx. Crop Sci. 47:1865-1877.

Robinson, A. F., Bridges, A. C., and Percival, A. E. 2004. New sources of resistance to the reniform (Rotylenchulus reniformis) and root-knot (Meloidogyne incognita) nematode in upland (Gossypium hirsutum L.) and sea island (G. barbadense L.) cotton. J. Cotton Sci. 8:191-197.

Robinson, A. F., Cook, C. G., and Percival, A. E. 1999. Resistance to Rotylenchulus reniformis and Meloidogyne incognita race 3 in the major cotton cultivars planted since 1950. Crop Sci. 39:850-858.

Robinson, A. F., Inserra, R. N., Caswell-Chen, E. P., Vovlas, N., and Troccoli, A. 1997. Rotylenchulus species: Identification, distribution, host ranges, and crop plant resistance. Nematropica 27:127-180.

Robinson, A. F., and Percival, A. E. 1997. Resistance to Meloidogyne incognita race 3 and Rotylenchulus reniformis in wild accessions of Gossypium hirsutum and G. barbadense from Mexico. J. Nematol. 29:746-755.

Romano, G. B., Sacks, E. J., Stetina, S. R., Robinson, A. F., Fang, D. D., Gutierrez, O. A., and Scheffler, J. A. 2009. Identification and genomic location of a reniform nematode (Rotylenchulus reniformis) resistance locus $\left(\right.$ Ren $\left.^{\text {ari }}\right)$ introgressed from Gossypium aridum into upland cotton (G. hirsutum). Theor. Appl. Genet. 120:139-150.

Rosso, M. N., Dubrana, M. P., Cimbolini, N., Jaubert, S., and Abad, P. 2005. Application of RNA interference to root-knot nematode genes encoding esophageal gland proteins. Mol. Plant-Microbe Interact. 18:615-620.

Ryan, C. A. 1990. Protease inhibitors in plants: Genes for improving defenses against insects and pathogens. Annu. Rev. Phytopathol. 28:425-449.

Sacks, E. J., and Robinson, A. F. 2009. Introgression of resistance to reniform nematode (Rotylenchulus reniformis) into upland cotton (Gossypium hirsutum) from Gossypium arboreum and a G. hirsutum/Gossypium aridum bridging line. Field Crops Res. 112:1-6.

Schafer, J. F. 1971. Tolerance to plant disease. Annu. Rev. Phytopathol. 9:235-252.

Schmidt, L. M., Hewlett, T. E., Green, A., Simmons, L. J., Kelley, K., Doroh, M., and Stetina, S. R. 2010. Molecular and morphological characterization and biological control capabilities of a Pasteuria ssp. parasitizing Rotylenchulus reniformis, the reniform nematode. J. Nematol. 42:207-217.

Schneider, K., Schiermeyer, A., Dolls, A., Koch, N., Herwartz, D., Kirchhoff, J., Fischer, R., Russell, S. M., Cao, Z., Corbin, D. R., Sastry-Dent, L., and Ainley, W. M., Webb, S. R., Schinkel, H., and Schillberg, S. 2016. Targeted gene exchange in plant cells mediated by a zinc finger nuclease double cut. Plant Biotechnol. J. 14:1151-1160.

Schrimsher, D. W., Lawrence, K. S., Sikkens, R. B., and Weaver, D. B. 2014. Nematicides enhance growth and yield of Rotylenchulus reniformis resistant cotton genotypes. J. Nematol. 46:365-375.

Sharma, T. R., Rai, A. K., Gupta, S. K., Vijayan, J., Devanna, B. N., and Ray, S. 2012. Rice blast management through host-plant resistance: Retrospect and prospects. Agric. Res. 1:37-52.

Sharp, P. A. 2001. RNA interference. Genes Dev. 15:485-490.

Sikkens, R. B., Bell, A. A., Wheeler, T. A., Overstreet, C., Weaver, D. B., Lawrence, K. S., and Nichols, R. L. 2012. Pages 761-767 in: Proceedings of the Beltwide Cotton Conferences, Orlando, FL.

Sikkens, R. B., Weaver, D. B., Lawrence, K. S., Moore, S. R., and van Santen, E. 2011. LONREN upland cotton germplasm response to Rotylenchulus reniformis inoculum level. Nematropica 41:68-74.

Singh, R. P., Hodson, D. P., Huerta-Espino, J., Jin, Y., Bhavani, S., Njau, P., Herrera-Foessel, S., Singh, P. K., Singh, S., and Govindan, V. 2011. The emergence of $\mathrm{Ug} 99$ races of the stem rust fungus is a threat to world wheat production. Annu. Rev. Phytopathol. 49:465-481.

Sobczak, M., Golinowski, W. A., and Grundler, F. M. W. 1999. Ultrastructure of feeding plugs and feeding tubes formed by Heterodera schachtii. Nematology 1:363-374.

Starr, J. L., Koenning, S. R., Kirkpatrick, T. L., Robinson, A. F., Roberts, P. A., and Nichols, R. L. 2007. The future of nematode management in cotton. J. Nematol. 39:283-294.

Starr, J. L., Smith, C. W., Ripple, K., Zhou, E., Nichols, R. L., and Faske, T. R. 2011. Registration of TAM RKRNR-9 and TAM RKRNR-12 germplasm lines of upland cotton resistant to reniform and root-knot nematodes. J. Plant Regist. 5:393-396.

Stetina, S. R., and Erpelding, J. E. 2016. Gossypium arboreum accessions resistant to Rotylenchulus reniformis. J. Nematol. 48:223-230.

Stetina, S. R., Russin, J. S., and McGawley, E. C. 1997. Replacement series: A tool for characterizing competition between phytoparasitic nematodes. J. Nematol. 29:35-42.

Stetina, S. R., Sciumbato, G. L., Young, L. D., and Blessitt, J. A. 2009. Cotton cultivars evaluated for tolerance to reniform nematode. Online publication. Plant Health Prog. doi.org/10.1094/PHP-2009-0312-01-RS

Stetina, S. R., and Young, L. D. 2006. Comparisons of female and egg assays to identify Rotylenchulus reniformis resistance in cotton. J. Nematol. 38:326-332.

Stetina, S. R., Young, L. D., Pettigrew, W. T., and Bruns, H. A. 2007. Effect of corn-cotton rotations on reniform nematode populations and crop yield. Nematropica 37:237-248.

Takasu, Y., Kobayashi, I., Tamura, T., Uchino, K., Sezutsu, H., and Zurovec, M. 2016. Precise genome editing in the silkworm Bombyx mori using TALENs and ds- and ssDNA donors: A practical approach. Insect Biochem. Mol. Biol. 78:29-38.

Thorp, K. R., Ale, S., Bange, M. P., Barnes, E. M., Hoogenboom, G., Lascano, R. J., McCarthy, A. C., Nair, S., Paz, J. O., Rajan, N., Reddy, K. R., Wall, G. W., and White, J. W. 2014. Development and application of processbased simulation models for cotton production: A review of past, present, and future directions. J. Cotton Sci. 18:10-47.

Urwin, P. E., Atkinson, H. J., Waller, D. A., and McPherson, M. J. 1995. Engineered oryzacystatin-I expressed in transgenic hairy roots confers resistance to Globodera pallida. Plant J. 8:121-131.

Urwin, P. E., Levesley, A., McPherson, M. J., and Atkinson, H. J. 2000. Transgenic resistance to the nematode Rotylenchulus reniformis conferred by Arabidopsis thaliana plants expressing proteinase inhibitors. Mol. Breed. 6:257-264.

Urwin, P. E., Lilley, C. J., and Atkinson, H. J. 2002. Ingestion of doublestranded RNA by preparasitic juvenile cyst nematodes leads to RNA interference. Mol. Plant-Microbe Interact. 15:747-752.

Urwin, P. E., Lilley, C. J., McPherson, M. J., and Atkinson, H. J. 1997. Resistance to both cyst- and root-knot nematodes conferred by transgenic Arabidopsis expressing a modified plant cystatin. Plant J. 12:455-461.

Usery, S. R., Jr., Lawrence, K. S., Lawrence, G. W., and Burmester, C. H. 2005. Evaluation of cotton cultivars for resistance and tolerance to Rotylenchulus reniformis. Nematropica 35:121-133.

Van Den Berg, E., Palomares-Rius, J. E., Vovlas, N., Tiedt, L. R., Castillo, P., and Subbotin, S. A. 2016. Morphological and molecular characterization of one new and several known species of the reniform nematode, Rotylenchulus Linford and Oliveira, 1940 (Hoplolaimidae: Rotylenchulinae), and a phylogeny of the genus. Nematology 18:67-107.

Wallace, T. P., Bowman, D., Campbell, B. T., Chee, P., Gutierrez, O. A., Kohel, R. J., McCarty, J., Myers, G., Percy, R., Robinson, F., Smith, W., Stelly, D. M., Stewart, J. M., Thaxton, P., Ulloa, M., and Weaver, D. B. 
2009. Status of the USA cotton germplasm collection and crop vulnerability. Genet. Resour. Crop Evol. 56:507-532.

Wallace, T. P., Golden, B., Thaxton, P. M., Scheffler, J., Lawrence, K. S., and Weaver, D. 2013. Agronomic performance of barbadense and longicalyx derived breeding lines. Page 1005 in: Proc. Beltwide Cotton Conf. San Antonio, TX.

Weaver, D. B. 2015. Cotton nematodes. Pages 547-570 in: Cotton. D. D. Fang and R. G. Percy, eds. American Society of Agronomy, Madison, WI.

Weaver, D. B., Lawrence, K. S., and Van Santen, E. 2007. Reniform nematode resistance in upland cotton germplasm. Crop Sci. 47:19-24.

Wendel, J. F., and Grover, C. E. 2015. Taxonomy and evolution of cotton genus, Gossypium. Pages 25-44 in: Cotton. D. D. Fang and R. G. Percy, eds. American Society of Agronomy, Madison, WI.

Westphal, A., and Smart, J. R. 2003. Depth distribution of Rotylenchulus reniformis under different tillage and crop sequence systems. Phytopathology 93:1182-1189.
Wood, A. J., Lo, T. W., Zeitler, B., Pickle, C. S., Ralston, E. J., Lee, A. H., Amora, R., Miller, J. C., Leung, E., Meng, X., Zhang, L., Rebar, E. J., Gregory, P. D., Urnov, F. D., and Meyer, B. J. 2011. Targeted genome editing across species using ZFNs and TALENs. Science 333:307.

Ye, W. M., Koenning, S. R., Khuo, K., and Liao, J. L. 2013. First report of Meloidogyne enterolobii on cotton and soybean in North Carolina, United States. Plant Dis. 97:1262.

Yik, C.-P., and Birchfield, W. 1984. Resistant germplasm in Gossypium species and related plants to Rotylenchulus reniformis. J. Nematol. 16:146-153.

Zamore, P. D., Tuschl, T., Sharp, P. A., and Bartel, D. P. 2000. RNAi: Doublestranded RNA directs the ATP-dependent cleavage of mRNA at 21 to 23 nucleotide intervals. Cell 101:25-33.

Zhan, X. D., Zhou, H. P., Chai, R. Y., Zhuang, J. Y., Cheng, S. H., and Cao, L. Y. 2012. Breeding of R8012, a rice restorer line resistant to blast and bacterial blight through marker-assisted selection. Rice Sci. 19:29-35. 